\section{Tree Age Influences Nutrient Partitioning among Annually Removed Aboveground Organs of Peach}

\author{
Qi Zhou \\ Department of Plant and Environmental Sciences, Clemson University, 105 \\ Collings Street, Biosystems Research Complex 204, Clemson, SC 29634; and \\ University of California Cooperative Extension, Small Farm Program, Santa \\ Clara County, 1553 Berger Drive, Building 1, San Jose, CA 95112

\section{Juan Carlos Melgar \\ Department of Plant and Environmental Sciences, Clemson University, 105 Collings Street, Biosystems Research Complex 204, Clemson, SC 29634}

Additional index words. mature trees, mineral nutrition, nutrient allocation, old trees, Prunus persica, rational fertilization

\begin{abstract}
The aim of this research was to assess how fruit tree age influences nutrient partitioning patterns in aboveground organs. We selected 6-year-old (mature) and 20year-old (old) 'Cresthaven' peach trees and measured the macronutrient concentrations in organs removed during pruning, thinning, harvesting, and leaf fall for 3 years. Then, we calculated the total amount of nutrients removed at each event and studied the partitioning patterns between mature and old peach trees. The results showed that mature peach trees had higher phosphorus $(P)$ and potassium $(K)$ concentrations in fruit mesocarp and fallen leaves than old trees. When we estimated the total nutrient content, mature peach trees allocated more nitrogen $(\mathrm{N}), \mathrm{P}, \mathrm{K}$, and calcium $(\mathrm{Ca})$ to pruned wood and harvested fruit but had less $\mathrm{N}$ and $\mathrm{Ca}$ in senescing leaves compared with old peach trees. The results of this study suggest that the different proportion of organs removed through orchard management practices from trees of different ages as well as the concentration of nutrients in these organs must be considered when estimating nutrient restitution needs and tree nutritional requirements.
\end{abstract}

Fruit tree nutritional requirements need to be fulfilled to assure adequate tree growth and maximum productivity, but current fertilization practices in commercial orchards often lead to excessive applications due to overestimation of tree needs (Carranca et al., 2018). Rational and orchard-optimized fertilization practices can play a pivotal role in alleviating soil nutrient losses and pollution of natural resources while improving fruit

Received for publication 15 Nov. 2019. Accepted for publication 7 Feb. 2020 .

Published online 11 March 2020.

This research was co-funded by South Carolina Peach Council (project number 2010511) and Southern Sustainable Agriculture Research and Education programs (project number GS17-174). Technical Contribution No. 6837 of the Clemson University Experiment Station. This material is based on work supported by NIFA/USDA under project number SC-1700530. We are very thankful to Douglas Bielenberg, Haibo Liu, and William Bridges for their suggestions to improve this article, and to Amanda Accampo, Brian Lawrence, and the farm crew at Clemson University Musser Fruit Research Farm for their assistance with data collection.

J.C.M. is the corresponding author. E-mail: jmelgar@ clemson.edu.

This is an open access article distributed under the CC BY-NC-ND license (https://creativecommons. org/licenses/by-nc-nd/4.0/). orchard sustainability and maintaining or improving productivity. It is well known that young nonfruiting trees and mature fruiting trees could respond differently to applied nutrients as a consequence of their nutrient uptake patterns and requirements (Carranca et al., 2018). For instance, $\mathrm{N}$ fertilization makes a much smaller contribution to leaf growth in mature pear trees (Sanchez et al., 1992) than in young trees (Quartieri et al., 2002), possibly because of a larger storage pool in mature trees and also because of greater competition from a larger fruit sink (Weinbaum et al., 2001). Nevertheless, anatomical and functional changes (e.g., xylem cell structure) continue long after the tree starts bearing fruit, and old trees show different anatomical, morphological, and physiological differences (e.g., hydraulic properties, water relations) compared with younger mature trees (Domec and Gartner, 2002; England and Attiwill, 2006; Irvine et al., 2004). Tree age also affects nutrient storage and remobilization in forest trees (Miller and Miller, 1987), but research studies of fruit trees have not been performed. Previous studies of forest trees suggest that nutrient resorption and remobilization become quantitatively more significant for older trees as the rate of nutrient uptake slows due to the decreasing xylem conductivity (Ryan and Yoder, 1997). Furthermore, the potential nutrient storage capac- ity increases due to the increasing root and trunk size in older trees (Netzer et al., 2017). These facts clearly stress the need for studying specific nutrient partitioning patterns in mature trees and older trees to gain a better understanding of their requirements and potentially improve orchard nutrient management.

Rational fertilization for fruit trees under field conditions should consider a balance between the amount of nutrients needed annually and the amount of nutrients removed through orchard management practices (pruned wood, thinned fruitlets, harvested fruits) or even natural events (fallen leaves). Many studies have used this approach for fruit trees (ElJendoubi et al., 2013; Roccuzzo et al., 2012; Rodrigues et al., 2012; Rufat and DeJong, 2001; Tagliavini and Scandellari, 2012), but the influence of age on tree nutrient partitioning has not yet been clarified. The objectives of this study were to measure nutrient removal and determine partitioning patterns in mature trees and old trees with the final goal of improving optimization of orchard fertilization. We hypothesized that mature trees will allocate more nutrients to pruning wood, whereas older trees will have more nutrients allocated to leaves or fruits.

\section{Materials and Methods}

Plant material and growth conditions. The experiment was performed at Clemson University Musser Fruit Research Farm (Seneca, SC; lat. $34.61^{\circ} \mathrm{N}$, long. $82.87^{\circ} \mathrm{W}$ ) for 3 years (2015-16, 2016-17, and 2017-18). Three mature peach trees that were 6 years old at the beginning of the experiment and five old peach trees that were 20 years old at the beginning of this study were used. All trees were of the cultivar Cresthaven grafted onto Bailey rootstock. Mature peach trees were trained into a $\mathrm{V}$ shape (with two scaffolds). Old trees were maintained as an open vase shape (with three to four scaffolds). Mature trees were spaced $1.5 \mathrm{~m}$ between trees and $6 \mathrm{~m}$ between rows, thereby resulting in a density of 1111 trees/ha. The old trees were spaced $4 \mathrm{~m}$ between trees and $6 \mathrm{~m}$ between rows, resulting in a density of 417 trees/ha. All trees were on the same research farm and were grown on the same soil type: clay-loam with a pH of 5.6 in water, $4.6 \mathrm{meq} /$ $100 \mathrm{~g}$ cation exchange capacity (CEC) (with $33.7 \% \mathrm{Ca}$ ), and $2.4 \%$ organic matter. The concentrations of mineral nutrients in the soil at the beginning of this research were: 50.4 $\mathrm{kg} \cdot \mathrm{ha}^{-1} \mathrm{P}, 137.9 \mathrm{~kg} \cdot \mathrm{ha}^{-1} \mathrm{~K}, 714.1 \mathrm{~kg} \cdot \mathrm{ha}^{-1} \mathrm{Ca}$, $121.1 \mathrm{~kg} \cdot \mathrm{ha}^{-1} \mathrm{Mg}$, with $7.4 \mathrm{ppm} \mathrm{NO}_{3}-\mathrm{N}$. Weather information including monthly average temperature $\left({ }^{\circ} \mathrm{C}\right)$ and precipitation (mm) from Jan. 2015 to Dec. 2017 are provided in Fig. 1. Granular fertilizer was broadcasted at rates and times following current fertilization management guidelines (Blaauw et al., 2019): $214 \mathrm{~kg} \cdot \mathrm{ha}^{-1} 19 \mathrm{~N}-8.3 \mathrm{P}-15.8 \mathrm{~K}$ in March and $137 \mathrm{~kg} \cdot \mathrm{ha}^{-1} 19 \mathrm{~N}-8.3 \mathrm{P}-15.8 \mathrm{~K}$ in July. Trees were irrigated twice per week for the last 3 weeks before harvesting using one inverted microjet sprinkler (Special Max-12; 


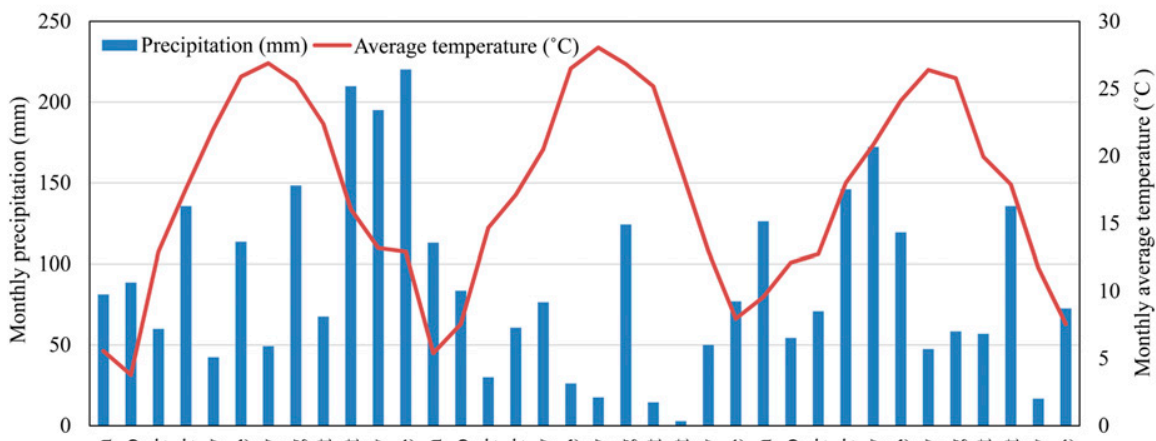

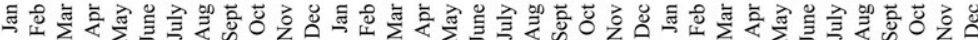

Months (from Jan. 2015 to Dec. 2017)

Fig. 1. Monthly precipitation $(\mathrm{mm})$ and average temperature $\left({ }^{\circ} \mathrm{C}\right)$ from Jan. 2015 to Dec. 2017 at the experimental farm located in Seneca, SC (lat. $34.61^{\circ} \mathrm{N}$, long. $82.87^{\circ} \mathrm{W}$ ).

Maxijet Inc., Dundee, FL) per tree. Averages of $70 \mathrm{~L} /$ tree/week and $375 \mathrm{~L} /$ tree/week were applied to the mature and the old trees, respectively. Disease, insect, and weed control were performed according to currently recommended rates and practices for commercial peach orchards in the southeastern United States (Blaauw et al., 2019). Trees were pruned at the beginning of February each year before budbreak. Summer pruning was not performed in these orchards. Thinning was conducted manually at the beginning of April, when the fruit diameter was $\approx 30 \mathrm{~mm}$. Harvest was performed at commercial maturity; for 'Cresthaven' in South Carolina, this occurs approximately during the third week of July. Average trunk diameters of mature trees and old trees were measured at the end of the experiment.

Sample collection, processing, and tissue analysis. The total amount of fresh weight (FW) removed at each nutrient removal event was recorded to calculate the total amount of nutrients removed annually and the percentage partitioned to each organ. Samples of the following organs were taken throughout the season: wood at winter pruning $(\approx 3 \mathrm{~kg} \mathrm{FW})$, fruitlets at thinning $(2 \mathrm{~kg} \mathrm{FW})$, fruits at harvest $(5 \mathrm{~kg} \mathrm{FW})$, and leaves during leaf fall ( $\approx 100$ leaves). Each year, 30 to 50 fully developed healthy leaves per tree were collected in July to test the nutrient status of the trees. Harvested fruits were divided into mesocarp and endocarp to test the mineral concentrations separately. After harvest and before leaf senescence started (mid to end of October), each tree was covered by a mosquito net (placed around the canopy of each tree and tied around the trunk) to collect all the falling leaves (by the beginning of December).

All samples were oven-dried at $70{ }^{\circ} \mathrm{C}$ and ground into a fine powder. Sample FW and dry weight (DW) were recorded to determine the total amount of nutrients removed at each event (pruning, thinning, harvesting, and leaf fall). Furthermore, $0.1 \mathrm{~g}$ of subsample was used for measuring the $\mathrm{N}$ concentration using a revised Dumas method (Jones et al., 1991).
Additionally, $0.25 \mathrm{~g}$ of the subsample was ashed in a muffle furnace at $600{ }^{\circ} \mathrm{C}$ for at least $16 \mathrm{~h}$, and the resulting ashes were dissolved in $10 \mathrm{~mL}$ of $\mathrm{HCl}(0.1 \mathrm{~N})$ and filtered at $0.42 \mu \mathrm{m}$. The $\mathrm{P}$ concentration was measured using the Murphy-Riley method (Murphy and Riley, 1962). Atomic absorption spectrophotometry (PinAAcle 500; Perkin Elmer, Waltham, MA) was used to measure $\mathrm{K}, \mathrm{Ca}$, and $\mathrm{Mg}$ concentrations. The nutrient content of each organ was calculated as the nutrient concentration in that organ multiplied by the DW of the organ collected. Then, nutrient partitioning was calculated as the nutrient content removed from each organ divided by the total nutrient content removed during the entire season.

Statistical analysis. Data were analyzed using an analysis of variance (JMP Pro 12; SAS, Cary, NC). Nutrient concentration data $(\% \mathrm{DW})$ were arcsine-transformed (arcsine of the square root) before analysis, and nontransformed means are presented. Differences between mature trees and old trees were detected using a $t$ test, with a $P$ value $\leq$ 0.05 indicating significance. Differences in nutrient partitioning percentage between mature trees and old trees were detected using a paired $t$ test.

\section{Results}

Leaf analysis. Annual leaf analysis (Table 1) showed that $\mathrm{N}, \mathrm{P}$, and $\mathrm{Ca}$ were in the sufficient nutrient range for all peach trees, and that $\mathrm{K}$ in mature trees and $\mathrm{Mg}$ in all trees were higher than the recommended sufficient range (Johnson, 2008). Mature peach trees accumulated higher concentrations of $\mathrm{K}$ (significant during 3 years) and $\mathrm{Ca}$ (significant in 2015 and 2017) than old trees. Other nutrients were significantly higher in mature trees compared with old trees only during one of the years: $\mathrm{P}$ was significant in 2017 and $\mathrm{Mg}$ was significant in 2016.

Nutrient concentrations of removed organs. Mature trees had significantly higher $\mathrm{K}$ concentrations in fruit mesocarp, thinned fruitlets, and fallen leaves and higher $\mathrm{P}$ concentrations in fruit mesocarp and fallen leaves than old trees (Table 1; differences detected during at least 2 years). There were no conclusive significant differences between mature trees and old peach trees in nutrient concentrations in pruned wood across all years, although mature trees showed lower concentrations of $\mathrm{N}, \mathrm{K}, \mathrm{Ca}$, and $\mathrm{Mg}$ than old trees during 1 year (2016). Similarly, thinned fruitlets from mature trees showed higher $\mathrm{P}, \mathrm{Ca}$, and $\mathrm{Mg}$ than old trees in 2017, and $\mathrm{Ca}$ concentration in fallen leaves tended to be higher in leaves from mature trees than in leaves from old trees, but these differences were only significant for 1 year.

Nutrient partitioning and removal. Mature peach trees allocated more N, P, K, and $\mathrm{Ca}$ to pruned wood but less $\mathrm{N}, \mathrm{Ca}$, and $\mathrm{Mg}$ to leaf fall than old trees (Fig. 2). Mature peach trees partitioned most of the $\mathrm{N}$ to harvested fruits (average of $37 \%$ for 3 years) and pruned wood (average of $36 \%$ for 3 years); however, most of the $\mathrm{N}$ in old trees was lost through leaf fall $(41 \%)$. All peach trees partitioned most of the $\mathrm{P}$ and $\mathrm{K}$ to harvested fruit $(\approx 50 \%)$. Calcium partitioning was very different from other nutrient elements, and most of the $\mathrm{Ca}$ was lost through pruning and leaf fall in both mature and old trees, whereas only $3 \%$ and $1 \%$ (for mature and old trees, respectively) of $\mathrm{Ca}$ were lost through fruit thinning and harvesting, respectively. Nevertheless, mature trees allocated more $\mathrm{Ca}$ to wood than old trees, and they allocated more $\mathrm{Ca}$ to leaves in fall than mature trees (Fig. 2). All peach trees partitioned most of the $\mathrm{Mg}$ to fallen leaves, but mature trees lost a lower percentage of $\mathrm{Mg}(39 \%)$ through this event compared with old trees $(58 \%)$.

Significant differences in total DW removed from the tree were observed between mature trees and old trees for every nutrient removal event (pruning, thinning, harvesting, and leaf fall, Table 2). Average removed DW $(\mathrm{kg})$ for mature trees and old trees were, respectively, 5.06 and 9.76 (pruned wood), 0.15 and 0.97 (thinned fruitlets), 4.35 and 14.28 (harvested fruits), and 1.78 and 8.57 (fallen leaves). The removed leaf-to-wood ratio, fruit-to-wood ratio, and fruit-to-leaf ratio were 0.35 and $0.88,0.86$ and 1.46 , and 2.44 and 1.67 for mature trees and old trees, respectively. The proportion of DW of pruning wood declined from $44.6 \%$ to $29.1 \%$ with increasing tree age, but the proportion of DW of fruit and fallen leaves increased from $38.4 \%$ to $42.5 \%$ and from $15.7 \%$ to $25.5 \%$, respectively, with increasing tree age.

Peach trees lost larger total amounts of $\mathrm{N}$, $\mathrm{K}$, and $\mathrm{Ca}$ through nutrient removal events compared with other macronutrients (data not shown); overall, old trees lost 2.9 times more N, 2.1 times more $\mathrm{P}, 2.5$ times more $\mathrm{K}$, 3 times more $\mathrm{Ca}$, and 3.4 times more $\mathrm{Mg}$ than mature trees (average of 3 years; data not shown). When calculated on a per tree basis, total nutrient removal (average of 3 years; $g$ / tree, for mature/old trees) was $121.3 / 350.3$ (N), 14.4/29.9 (P), 178.6/448.4 (K), 102.7/ $306(\mathrm{Ca})$, and 39/130.7 (Mg) 
Table 1. Concentrations of $\mathrm{N}, \mathrm{P}, \mathrm{K}, \mathrm{Ca}$, and $\mathrm{Mg}(\% \mathrm{DW})$ of different organs collected during 3 years (2015-17) from mature and old peach trees.

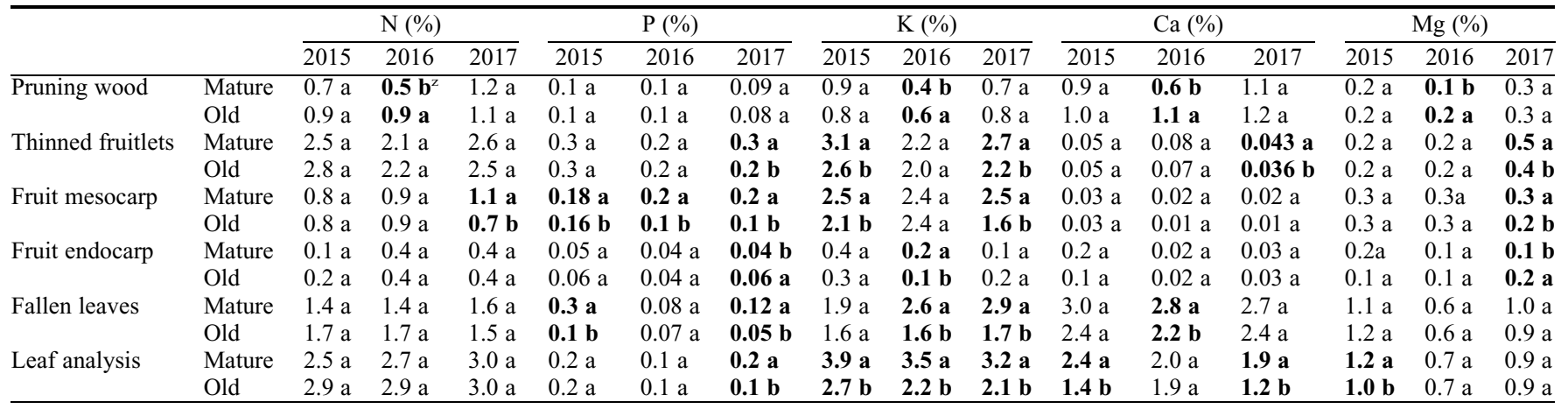

${ }^{\mathrm{z}}$ Bold values with different letters indicate significant differences (between mature and old trees) at $P \leq 0.05$ measured by $t$ test.

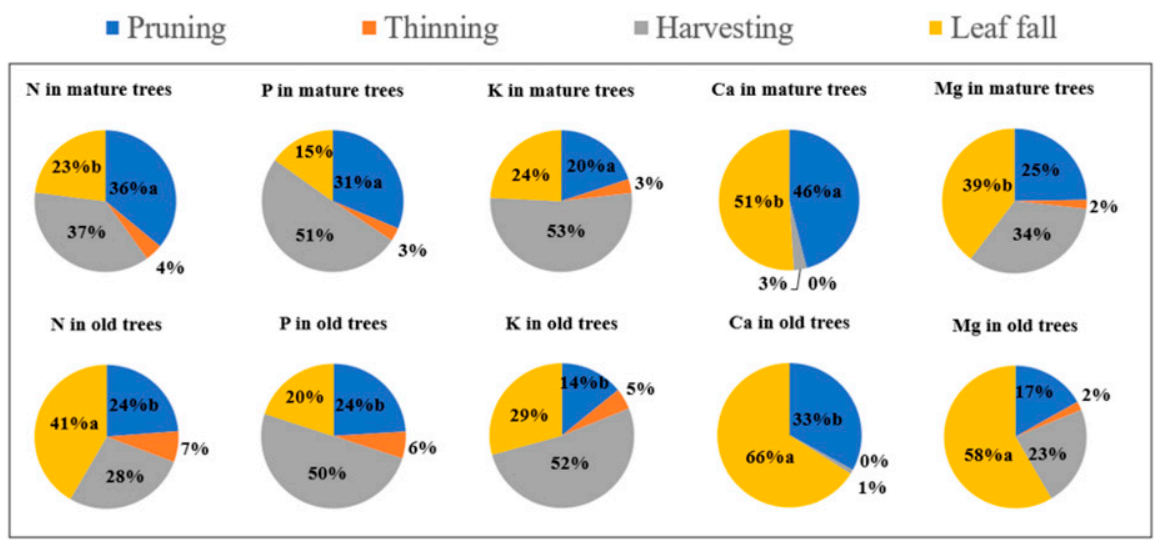

Fig. 2. Nutrient allocation to pruned wood, thinned fruitlets, harvested fruit, and leaves fallen based on estimated total nutrient content of peach trees of different ages during 3 years. Values presented in the figure are the average of 3 years. Different letters indicate significant differences (between mature and old trees) measured by the paired $t$ test at $P \leq 0.05$ level.

\section{Discussion}

Tree age affected the nutrient allocation to aboveground organs due to changes in the amount of biomass removed and the concentration of nutrients in these organs. The amount of biomass removed through orchard management practices such as pruning, thinning, and harvesting or through natural phenomena such as leaf fall was different in mature and old trees. Specifically, old trees had almost three-times (average) more annual DW removed throughout the year.

A previous study by Scandellari et al., (2010) showed that the DW collected during each nutrient removal event was different for trees of different ages, with annual DW of abscised leaves and fruit yield increasing with tree age. Nevertheless, the nutrient concentrations in the organs from trees of different ages were not assessed in that study. Hence, our study provides novel data for nutrient concentrations of removed organs from fruit trees of different ages.

We consistently recorded decreasing $\mathrm{P}$ and $\mathrm{K}$ concentrations in fruit at harvest and leaves fallen in autumn with increasing tree age. Hosseinifard et al. (2010) also reported lower leaf $\mathrm{K}$ concentrations in older pistachio trees (20 and 40 years old) compared with younger mature trees (10 years old). One of the possible reasons for these differences between mature trees and old trees could be the sink strength and competition due to different canopy size. Therefore, fruit and leaves of mature peach trees had weaker sink competition and could attain higher nutrient concentrations (particularly highly mobile nutrients such as $\mathrm{P}$ and $\mathrm{K}$ ) than old trees. We did not measure tree canopy size, but the average trunk diameters of old and mature trees were $259 \mathrm{~mm}$ and $126 \mathrm{~mm}$, respectively, and the amount of biomass removed from old trees was significantly higher than that of mature trees, as we already pointed out.

The increased concentrations of $\mathrm{P}$ and $\mathrm{K}$ in summer or fall organs (leaves, fruit, fallen leaves) of mature trees did not correspond with higher concentrations of nutrients in dormant organs (pruning wood) the following season. However, old trees had higher concentrations of $\mathrm{K}, \mathrm{Ca}$, and $\mathrm{Mg}$ in wood pruned in 2016 after leaves sampled in Summer 2015 had shown lower $\mathrm{K}, \mathrm{Ca}$, and $\mathrm{Mg}$ concentrations compared with mature trees. Low concentrations of a given nutrient in fallen leaves did not always correlate with high concentrations of that nutrient in pruned wood the following winter (pruned wood is only part of the nutrient reserves, and it is well known that significant amounts of nu- trients are stored below the graft union and in the root system) (Lawrence and Melgar, 2018). Nevertheless, this pattern seems to indicate that old trees may be more efficient at resorbing nutrients before leaf fall and accumulating them in the reserves. As reported by Frak et al. (2002) and Weinbaum and Van Kessel (1998), the nutrient resorption and remobilization become quantitatively more significant for older trees as the rate of nutrient uptake slows while their potential storage capacity for nutrient increases. Larger storage capacity could also enable older trees to have higher efficiency for recycling nutrients from senescing leaves than mature trees, which would compensate for the decreasing nutrient uptake from roots. Furthermore, the leaf/wood ratio of peach trees of different ages may have also had a role in their efficiency for nutrient resorption. Similar to previous research by Scandellari et al. (2010), our results revealed that the fallen leaf DW/pruned wood DW ratio for mature peach trees $(0.35)$ was much smaller than that of the old trees $(0.88)$. Therefore, considering that $\approx 50 \%$ of leaf $\mathrm{N}$ is resorbed before leaf fall (Niederholzer et al., 2001), the increased fallen leaf/pruned wood ratio seems to imply higher nutrient resorption during leaf senescence in old peach trees compared with mature trees.

In this study, we also found that the distribution of nutrient contents in the organs removed from peach trees also varied significantly with tree age. In addition, the proportion of DW allocated to the pruning wood (wood DW/total DW removed) declined greatly with increasing tree age, and the allocation percentages for $\mathrm{N}, \mathrm{P}, \mathrm{K}$, and $\mathrm{Ca}$ to pruning wood were smaller for old trees than for mature trees. However, the partitioning of $\mathrm{N}, \mathrm{Ca}$, and $\mathrm{Mg}$ to senescing leaves of old trees increased significantly compared with those of mature trees. Although we did not use trace elements in this study, we hypothesized that the higher values in old trees may have been due to different nutrient uptake patterns and/or direct allocation to leaves throughout the season of mature and old trees (there was no indication of nutrient movement to senescing leaves; $\mathrm{N}$ concentration in fallen leaves was lower than that in summer leaves in both mature and old trees; $\mathrm{Ca}$ is immobile in the phloem; and $\mathrm{Mg}$ 


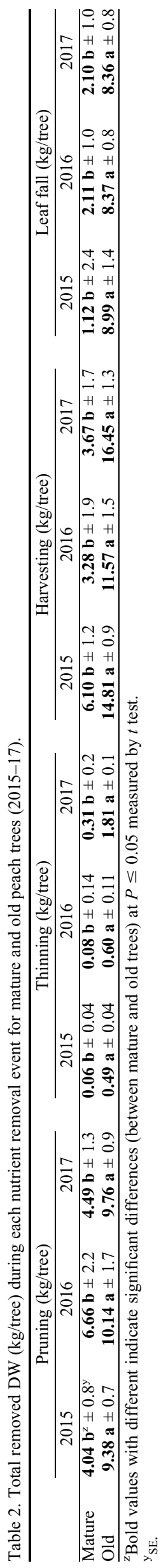

concentration did not change between summer leaves and fallen leaves). Other researchers have reported similar results for N only; for instance, Greenham (1979) reported that $\approx 48 \%$ and $28 \%$ of $\mathrm{N}$ were partitioned to woody tissues in mature and old apple trees, respectively, but that $36 \%$ and $43 \%$ of $N$ were lost through leaf fall in mature and old trees, respectively. We also observed that mature trees tend to have higher leaf nutrient concentrations than old trees but partitioned less nutrients to senescing leaves due to a lower percentage of DW from fallen leaves. However, nutrient allocation to fruit was unaffected by tree age, although mature trees (with smaller canopy) had higher concentrations of nutrients such as $\mathrm{P}$ and $\mathrm{K}$ in fruit than old trees.

The fact that increasing tree age could affect tree canopy size, leaf/wood ratio, DW distribution, and nutrient partitioning indicates the relevance of determining the nutrient requirements of mature peach trees and old trees to estimate the tree nutrient balance and nutrient restitution needed for maintaining adequate nutritional status. Because tree size considerably increases with age, different values of DW removal observed in trees of different ages may primarily be a consequence of tree growth and size (Scandellari et al., 2010). A limitation of our study was that our mature and old trees had different pruning systems, which also affected tree size. Nevertheless, the goal of this study was to optimize fertilization at the orchard level; in this regard, nutrient removal and restitution needs should be considered per surface area, and the DW removal per surface area from trees of different sizes is buffered by the different planting density of each pruning system.

The cumulative amount of nutrients taken up by a tree in 1 year could be estimated by the nutrient content in the yearly removed organs. Considering the yield (average FW of harvested fruits for 3 years, in $\mathrm{kg} /$ tree, which was $28.95 / 83.21$ for mature peach trees and old trees, respectively), the amounts of nutrients removed per ton of fruit were $3.8 / 3.8 \mathrm{~kg}$ $\mathrm{N}, 0.5 / 0.3 \mathrm{~kg} \mathrm{P}, 5.6 / 4.9 \mathrm{~kg} \mathrm{~K}, 3.2 / 3.4 \mathrm{~kg}$ $\mathrm{Ca}$, and $1.2 / 1.4 \mathrm{~kg} \mathrm{Mg}$ for mature peach trees and old trees, respectively. These data were lower than the previous findings by El-Jendoubi et al. (2013), who reported that the amounts of nutrients removed per ton of fruit were 6 to $8.8 \mathrm{~kg} \mathrm{~N}, 0.7$ to $1.0 \mathrm{~kg}$ $\mathrm{P}, 7.3$ to $8.5 \mathrm{~kg} \mathrm{~K}, 9.5$ to $13.3 \mathrm{~kg} \mathrm{Ca}$, and 1.3 to $1.7 \mathrm{~kg} \mathrm{Mg}$, probably due to the summer pruning that was performed during their study, because branches and leaves pruned in summer could contain higher nutrient concentrations and increase nutrient loss.

Overall, mature peach trees removed fewer nutrients during every nutrient removal event compared with old trees, mainly due to the aforementioned differences in the total removed amount of DW of mature trees and old trees. Although the objective of this study was to determine nutrient removal from trees of different ages to obtain a better estimate of nutrient restitution, we were aware that a portion of nutrients were resorbed before senescence and stored in permanent structures such as trunks and roots. Nutrient resorption and translocation to permanent tree organs were not analyzed in this study due to the need for labeled nutrients, the destructive nature of these measurements (trunk and root), and the limited number of trees available. Root and trunk DW in adult peach trees can vary between $22 \%$ and $37 \%$ of the total tree biomass (Rufat and DeJong, 2001), and although the nutrient concentration and contents have been assessed in other studies of peach (El Jendoubi et al., 2013), assessing the amount of nutrients resorbed to these organs in field studies is challenging, and studies that successfully account for nutrients stored in the roots are not common (Millard and Grelet, 2010) and depend on the tree species (Feigenbaum et al., 1987; Rosecrance et al., 1998). Therefore, this is an area that would benefit field research studies and increase our understanding of whole-tree nutrient cycling.

In summary, results of this research indicate that old peach trees allocated a smaller percentage of $\mathrm{N}, \mathrm{P}, \mathrm{K}$, and $\mathrm{Ca}$ to pruning wood but a higher portion of $\mathrm{N}, \mathrm{Ca}$, and $\mathrm{Mg}$ to senescing leaves than mature trees. Old trees seemed to translocate more nutrients back to the permanent structures during leaf senescence, suggesting they may recycle nutrients more efficiently. However, this hypothesis needs to be confirmed by resorption studies using labeled elements. Tree age (due to increased tree growth) also affected peach tree total nutrient removal and DW partitioning, but there were no differences in nutrient allocation to fruit of mature and old trees Overall, the effect of tree age should be considered when planning fertilization programs because these differences can affect orchard productivity. Therefore, tree age should be considered together with other orchard management practices and information specific to each orchard such as tree nutritional status of the previous year, annual yield, pruning intensity (including execution of summer pruning), and in-field chipping of orchard prunings followed by spreading them on or incorporating them into the ground in a rational fertilization program.

\section{Literature Cited}

Blaauw, B., P. Brannen, B. Bellinger, D. Lockwood, and D. Ritchie. 2019. 2019 Southeastern peach, nectarine and plum pest management and culture guide. University of Georgia Extension, Athens, GA.

Carranca, C., G. Brunetto, and M. Tagliavini. 2018. Nitrogen nutrition of fruit trees to reconcile productivity and environmental concerns. Plants 7:4.

Domec, J.C. and B.L. Gartner. 2002. Age-and position-related changes in hydraulic versus mechanical dysfunction of xylem: Inferring the design criteria for Douglas-fir wood structure. Tree Physiol. 22(2-3):91-104. 
El-Jendoubi, H., J. Abadía, and A. Abadía. 2013. Assessment of nutrient removal in bearing peach trees (Prunus persica L. Batsch) based on whole tree analysis. Plant Soil 369:421-437.

England, J.R. and P.M. Attiwill. 2006. Changes in leaf morphology and anatomy with tree age and height in the broadleaved evergreen species, Eucalyptus regnans F. Muell. Trees 20:79-90.

Feigenbaum, S., H. Bielorai, Y. Erner, and S. Dasberg. 1987. The fate of ${ }^{15} \mathrm{~N}$ labeled nitrogen applied to mature citrus trees. Plant Soil 97:179-187.

Frak, E., P. Millard, X. Le Roux, S. Guillaumie, and R. Wendler. 2002. Coupling sap flow velocity and amino acid concentrations as an alternative method to ${ }^{15} \mathrm{~N}$ labeling for quantifying nitrogen remobilization by walnut trees. Plant Physiol. 130(2):1043-1053.

Greenham, D.W.P. 1979. Nutrient cycling: The estimation of orchard nutrient uptake. Acta Hort. 92:345-352.

Hosseinifard, S.J., H. Khademi, and M. Kalbasi. 2010. Different forms of soil potassium as affected by the age of pistachio (Pistacia vera L.) trees in Rafsanjan, Iran. Geoderma 155(34):289-297.

Irvine, J., B.E. Law, M.R. Kurpius, P.M. Anthoni, D. Moore, and P.A. Schwarz. 2004. Age-related changes in ecosystem structure and function and effects on water and carbon exchange in ponderosa pine. Tree Physiol. 24(7):753-763.

Johnson, R.S. 2008. Nutrient and water requirements of peach trees, p. 303-331. In: D.R. Layne and D. Bassi (eds.). The peach, botany, production and uses. CABI, Cambridge, MA.

Jones, J.B., Jr., B. Wolf, and H.A. Mills. 1991. Plant analysis handbook. A practical sampling, preparation, analysis and interpretation guide. Micro-Macro Publishing, Inc., Athens, GA.

Lawrence, B.T. and J.C. Melgar. 2018. Variable fall climate influences nutrient resorption and reserve storage in young peach trees. Front. Plant Sci. 9:1819.

Millard, P. and G.-A. Grelet. 2010. Nitrogen storage and remobilization by trees: Ecophysiological relevance in a changing world. Tree Physiol. 30:1083-1095.

Miller, H.G. and J.D. Miller. 1987. Nutritional requirements of Sitka spruce. Proc. R. Soc. Edinb. 93:75-83.

Murphy, J. and J.P. Riley. 1962. A modified single solution method for the determination of phosphate in natural waters. Anal. Chim. Acta 27:31-36.

Netzer, F., C. Schmid, C. Herschbach, and H. Rennenberg. 2017. Phosphorus-nutrition of European beech (Fagus sylvatica L.) during annual growth depends on tree age and P-availability in the soil. Environ. Exp. Bot. 137:194-207.

Niederholzer, F.J.A., T.M. DeJong, J.-L. Saenz, T.T. Muraoka, and S.A. Weinbaum. 2001 Effectiveness of fall versus spring soil fertilization of field-grown peach trees. J. Amer. Soc. Hort. Sci. 125:644-648.

Quartieri, M., P. Millard, and M. Tagliavini. 2002. Storage and remobilisation of nitrogen by pear (Pyrus communis L.) trees as affected by timing of N supply. Eur. J. Agron. 17(2):105-110.

Roccuzzo, G., D. Zanotelli, M. Allegra, A. Giuffrida, B.F. Torrisi, A. Leonardi, A. Quiñones, F. Intrigliolo, and M. Tagliavini. 2012. Assessing nutrient uptake by field-grown orange trees. Eur. J. Agron. 41:73-80.

Rodrigues, M.Â., I.Q. Ferreira, A.M. Claro, and M. Arrobas. 2012. Fertilizer recommendations for olive based upon nutrients removed in crop and pruning. Scientia Hort. 142:205-211.

Rosecrance, R.C., S.A. Weinbaum, and P.H. Brown. 1998. Alternate bearing affects nitrogen, phosphorus, potassium and starch storage pools in mature pistachio trees. Ann. Bot. $82: 463-470$.

Rufat, J. and T.M. DeJong. 2001. Estimating seasonal nitrogen dynamics in peach trees in response to nitrogen availability. Tree Physiol. 21:1133-1140.

Ryan, M.G. and B.J. Yoder. 1997. Hydraulic limits to tree height and tree growth. Bioscience 47(4):235-242.

Sanchez, E.E., T.L. Righett, D. Sugar, and P.B. Lombard. 1992. Effects of timing of nitrogen application on nitrogen partitioning between vegetative, reproductive, and structural components of mature 'Comice' pears. J. Hort. Sci. 67(1):51-58.

Scandellari, F., M. Ventura, D. Malaguti, C. Ceccon, G. Menarbin, and M. Tagliavini. 2010. Net primary productivity and partitioning of absorbed nutrients in field-grown apple trees. Acta Hort. 868:115-122.

Tagliavini, M. and F. Scandellari. 2012. Methodologies and concepts in the study of nutrient uptake requirements and partitioning in fruit trees. Acta Hort. 984:47-56.

Weinbaum, S.A., P.H. Brown, and R.S. Johnson. 2001. Application of selected macronutrients (N, $\mathrm{K})$ in deciduous orchards: Physiological and agrotechnical perspectives. Acta Hort. 594:59-64.

Weinbaum, S. and C. Van Kessel. 1998. Quantitative estimates of uptake and internal cycling of ${ }^{14} \mathrm{~N}$-labeled fertilizer in mature walnut trees. Tree Physiol. 18(12):795-801. 